\title{
Pyrogenic carbon from tropical savanna burning: production and stable isotope composition
}

\author{
G. Saiz ${ }^{1, *}$, J. G. Wynn ${ }^{2}$, C. M. Wurster ${ }^{1}$, I. Goodrick ${ }^{1}$, P. N. Nelson ${ }^{1}$, and M. I. Bird ${ }^{1}$ \\ ${ }^{1}$ College of Science, Technology and Engineering and Centre for Tropical Environmental and Sustainability Science, \\ James Cook University, P.O. Box 6811, Cairns, Queensland, 4870, Australia \\ ${ }^{2}$ School of Geosciences, University of South Florida, 4202 East Fowler Ave, NES107, Tampa, Florida 33620, USA \\ * now at: Institute of Meteorology and Climate Research, Karlsruhe Institute of Technology, \\ Garmisch-Partenkirchen, Germany
}

Correspondence to: G. Saiz (gustavo.saiz@kit.edu)

Received: 25 September 2014 - Published in Biogeosciences Discuss.: 28 October 2014

Revised: 10 February 2015 - Accepted: 16 February 2015 - Published: 20 March 2015

\begin{abstract}
Widespread burning of mixed tree-grass ecosystems represents the major natural locus of pyrogenic carbon $(\mathrm{PyC})$ production. $\mathrm{PyC}$ is a significant, pervasive and yet poorly understood "slow-cycling" form of carbon present in the atmosphere, hydrosphere, soils and sediments. We conducted 16 experimental burns on a rainfall transect through northern Australian savannas with $\mathrm{C}_{4}$ grasses ranging from 35 to $99 \%$ of total biomass. Residues from each fire were partitioned into $\mathrm{PyC}$ and further into recalcitrant (HyPyC) components, with each of these fluxes also partitioned into proximal components $(>125 \mu \mathrm{m})$, likely to remain close to the site of burning, and distal components $(<125 \mu \mathrm{m})$, likely to be transported from the site of burning. The median (range) PyC production across all burns was 16.0 (11.5) \% of total carbon exposed (TCE), with HyPyC accounting for 2.5 (4.9) \% of TCE. Both PyC and HyPyC were dominantly partitioned into the proximal flux. Production of HyPyC was strongly related to fire residence time, with shorter duration fires resulting in higher HyPyC yields. The carbon isotope $\left(\delta^{13} \mathrm{C}\right)$ compositions of $\mathrm{PyC}$ and $\mathrm{HyPyC}$ were generally lower by $1-3 \%$ o relative to the original biomass, with marked depletion up to $7 \%$ for grasslands dominated by $\mathrm{C}_{4}$ biomass. $\delta^{13} \mathrm{C}$ values of $\mathrm{CO}_{2}$ produced by combustion were computed by mass balance and ranged from $\sim 0.4$ to $1.3 \%$. The depletion of ${ }^{13} \mathrm{C}$ in $\mathrm{PyC}$ and $\mathrm{HyPyC}$ relative to the original biomass has significant implications for the interpretation of $\delta^{13} \mathrm{C}$ values of savanna soil organic carbon and of ancient $\mathrm{PyC}$ preserved in the geologic record, as well as for global ${ }^{13} \mathrm{C}$ isotopic disequilibria calculations.
\end{abstract}

\section{Introduction}

Pyrogenic carbon (PyC) describes carbon (C) in a continuum of thermally altered materials produced by incomplete biomass combustion and ranging from partly charred organic matter to condensed polyaromatic compounds (Hammes et al., 2007; Masiello, 2004). Components of the PyC continuum have been referred to by a variety of other terms, including soot, char and black carbon (Bird and Gröcke, 1997; Seiler and Crutzen, 1980). This range of names reflects the compositional complexity of $\mathrm{PyC}$ and the wide array of analytical methods employed for its quantification (Hammes et al., 2007; Ascough et al., 2009). While there is wide recognition of the large relevance of PyC affecting environmental processes (Bird et al., 1999; Cope and Chaloner, 1980; Lehmann et al., 2008; Zimmermann et al., 2012), it remains a poorly understood component of the global carbon cycle (Forbs et al., 2006). Estimates of global PyC production rates have varied considerably since first reported (Seiler and Crutzen, 1980). The difficulty in establishing a reliable estimate of PyC production rates arises from the range of definitions used for $\mathrm{PyC}$, usually operationally defined by the analytical technique used, and also by widely divergent experimentally derived estimates of $\mathrm{PyC}$ production (Forbes et al., 2006). Calculations of the size of a global atmospheric C sink to $\mathrm{PyC}$ are also complicated because some components of PyC appear to be susceptible to degradation on comparatively short timescales (Bird et al., 1999; Zimmermann et al., 2012), while some are resistant to degradation, remain- 
ing in soils and sediments for thousands to millions of years (Cope and Chaloner, 1980; Lehmann et al., 2008; Masiello and Druffel, 1998). While the use of different techniques does indeed lead to different results, it has become quite apparent over the years that the $\mathrm{PyC}$ continuum is also associated with a PyC degradation continuum (Bird et al., 2015).

Of the total PyC produced by biomass burning, it has been estimated that $>90 \%$ remains (initially) close to the site of production and $<10 \%$ is emitted into the atmosphere as aerosols (Kuhlbusch et al., 1996), with much of the PyC emitted into the atmosphere being ultimately deposited in the oceans (Bird et al., 2015). PyC that remains on the ground will potentially (i) be re-combusted in subsequent fire events (Saiz et al., 2014; Santín et al., 2013) (ii) be re-mineralised by biotic/abiotic processes (Saiz et al., 2014; Santín et al., 2013; Zimmerman, 2010; Zimmermann et al., 2012), (iii) be remobilised by bioturbation, wind or water in either particulate (Major et al., 2010; Rumpel et al., 2006) or dissolved form (Dittmar, 2008; Dittmar et al., 2012) and/or (iv) accumulate in the soil organic carbon (SOC) pool (Lehmann et al., 2008).

With fire return intervals of 5 years or less (Furley et al., 2008), tropical savannas are major loci of global annual PyC production. Forbes et al. (2006) estimated the annual PyC production rate from savanna fires to be $4-40 \mathrm{Tg} \mathrm{yr}^{-1}$ (of a global total of $50-270 \mathrm{Tg} \mathrm{yr}^{-1}$ ), assuming $1-2 \%$ of carbon exposed to fires was converted to PyC. Van der Werf et al. (2010) estimated that $39 \%$ of a total of $2.1 \mathrm{Tg} \mathrm{yr}^{-1}$ $\mathrm{PyC}$ emissions into the atmosphere derived from the burning of tropical savannas and grasslands (including extra-tropical grasslands; http://www.falw.vu/), whereas Bond et al. (2004) estimated savanna burning at $51 \%$ of total "open-burning" emissions.

In tropical savannas, woody vegetation uses the $\mathrm{C}_{3}$ photosynthetic pathway $\left(\delta^{13} \mathrm{C}<24 \%\right.$ ), whereas grasses primarily use the $\mathrm{C}_{4}$ photosynthetic pathway $\left(\delta^{13} \mathrm{C}\right.$ values $\geq 15 \%$ o (O'Leary, 1988). Randerson et al. (2005) estimated that $31 \%$ of global fire emissions have a $\mathrm{C}_{4}$ origin and that $20 \%$ of total $\mathrm{C}_{4}$ biomass returns to the atmosphere each year as a result of fire. The production of $\mathrm{PyC}$ from $\mathrm{C}_{3}$ biomass generally has little impact on the $\delta^{13} \mathrm{C}$ of the $\mathrm{PyC}$ relative to the precursor biomass ( $<\sim 1 \%$; Krull et al., 2003; Das et al., 2010). However, Krull et al. (2003) found that $\delta^{13} \mathrm{C}$ values of PyC from $\mathrm{C}_{4}$ grasses were $1.5-5 \%$ lower than precursor biomass. Das et al. (2010) also reported PyC products with $\delta^{13} \mathrm{C}$ values lower than original biomass, but noted a difference between "smoke" $\left({ }^{13} \mathrm{C}\right.$ value lower by $0.5-7.2 \%$, species dependent) and "ash" (generally lower by up to $3.5 \%$ o). Therefore, while $\delta^{13} \mathrm{C}$ values provide a useful tracer of the fate of treeand grass-derived $\mathrm{PyC}$ both during and after formation, the robust interpretation of $\delta^{13} \mathrm{C}$ values requires a more nuanced understanding of the processes controlling fractionation effects.

At the global scale, models of terrestrial ${ }^{13} \mathrm{C}$ discrimination suggest about one-quarter of the gross primary produc- tivity (GPP) of the terrestrial biosphere is attributable to the $\mathrm{C}_{4}$ photosynthetic pathway (Lloyd and Farquhar, 1994; Still et al., 2003). In contrast, recent work has suggested the fraction of $\mathrm{C}_{4}$-derived biomass in SOC in savanna systems is much lower than GPP estimates would imply, partly due to $\mathrm{C}_{4}$-derived $\mathrm{C}$ decomposing faster than $\mathrm{C}_{3}$-derived $\mathrm{C}$ in the soil (Wynn and Bird, 2007; Wynn et al., 2006). However, it is also plausible that during savanna burning (i) $\mathrm{C}_{4}$ carbon is preferentially combusted relative to $\mathrm{C}_{3}$ woody biomass and/or (ii) $\mathrm{C}_{4}$ biomass produces finer $\mathrm{PyC}$ particles than $\mathrm{C}_{3}$ woody biomass, and thus $\mathrm{C}_{4}$-derived $\mathrm{PyC}$ is more likely to be exported by wind, leading to a relative accumulation of $\mathrm{C}_{3}$ derived $\mathrm{PyC}$ at the site of burning (and ultimately in the soil), with $\mathrm{C}_{4}$-derived $\mathrm{PyC}$ preferentially accumulating in sites remote to burning and particularly in lacustrine sediments and the ocean (Bird and Cali, 1998). Differences between the $\delta^{13} \mathrm{C}$ values of $\mathrm{C}$ released into the atmosphere vs. $\delta^{13} \mathrm{C}$ values of the $\mathrm{C}$ as it was fixed, or vs. the $\delta^{13} \mathrm{C}$ value of the SOC pool, are referred to as "isotopic disequilibria" in mass balance models of atmospheric $\mathrm{CO}_{2}$ (Alden et al., 2010; Enting et al., 1995). In savannas, large disequilibria are largely due to differences in the residence time of $\mathrm{C}_{3}$ and $\mathrm{C}_{4}$ biomass (Randerson et al., 2005; Ciais et al., 1999, 2005; Buchmann and Ehleringer, 1998).

Quantification of the contribution of savanna fires to terrestrial isotopic disequilibrium due to potential differences in the residence times of $\mathrm{C}_{3}$ - and $\mathrm{C}_{4}$-derived $\mathrm{C}$ in vegetation and soil is important for (i) correctly interpreting soil and palaeosol carbon isotope data (Cerling et al., 2011), (ii) informing modelling studies that use variations in the $\mathrm{CO}_{2} \delta^{13} \mathrm{C}$ record to apportion sources and sinks of $\mathrm{CO}_{2}$ (Randerson et al., 2005; Ciais et al., 1999, 2005) and (iii) enabling an assessment of physical redistribution biases that might complicate the interpretation of the $\delta^{13} \mathrm{C}$ record of PyC in terrestrial, lacustrine and marine sedimentary records (Bird and Ascough, 2012).

In this paper, we use a series of controlled field burning experiments in four savanna environments of northeastern Australia, where the strong climatic gradient exerts a major influence on vegetation structure existing across this large region (Table 1, Figs. 1-2). The experiments were designed to quantify the production and fate of $\mathrm{PyC}$ during savanna burning. Specifically, we seek to determine (i) the proportion of savanna biomass that is converted to $\mathrm{PyC}$ during burning, (ii) the distribution of this $\mathrm{PyC}$ between different size classes and (iii) the proportion of $\mathrm{PyC}$ fraction remaining on the ground against that exported as fine particulates during burning.

Our study takes advantage of controlled conditions, and a purpose-built field apparatus designed to determine the stocks and fluxes of $\mathrm{PyC}$ from fires occurring in a variety of savanna types (Fig. 3, see Sect. 2.2). In addition, we used mass and carbon isotope balances to test the hypothesis that there is a "savanna isotope disequilibrium effect" (SIDE) during burning, which leads to (i) overall more negative $\delta^{13} \mathrm{C}$ values for PyC produced in savanna fires due to the more 
Table 1. Characteristics of the studied sites.

\begin{tabular}{lrrrrr}
\hline Site & $\begin{array}{r}\text { Latitude } \\
\left({ }^{\circ} \mathrm{S}\right)\end{array}$ & $\begin{array}{r}\text { Longitude } \\
\left({ }^{\circ} \mathrm{E}\right)\end{array}$ & $\begin{array}{r}\text { MAP } \\
(\mathrm{mm})\end{array}$ & $\begin{array}{r}\text { MAT } \\
\left({ }^{\circ} \mathrm{C}\right)\end{array}$ & $\begin{array}{r}\mathrm{CC} \\
(\%)\end{array}$ \\
\hline DCR (Davies Creek NP) & 16.997 & 145.574 & 2050 & 21.3 & 55 \\
BRK (Brooklyn Nature Refuge) & 16.586 & 145.155 & 1650 & 22.5 & 40 \\
UND (Undara NP) & 18.208 & 144.658 & 795 & 23.6 & 30 \\
MIT (Mitchell Grassland) & 21.403 & 144.677 & 435 & 24.3 & 5 \\
\hline
\end{tabular}

MAP is mean annual precipitation and MAT is mean annual temperature. Climate data derived from the

Australian Bureau of Meteorology. For the calculation of woody canopy cover (CC), the reader is referred to Domingues et al. (2010).

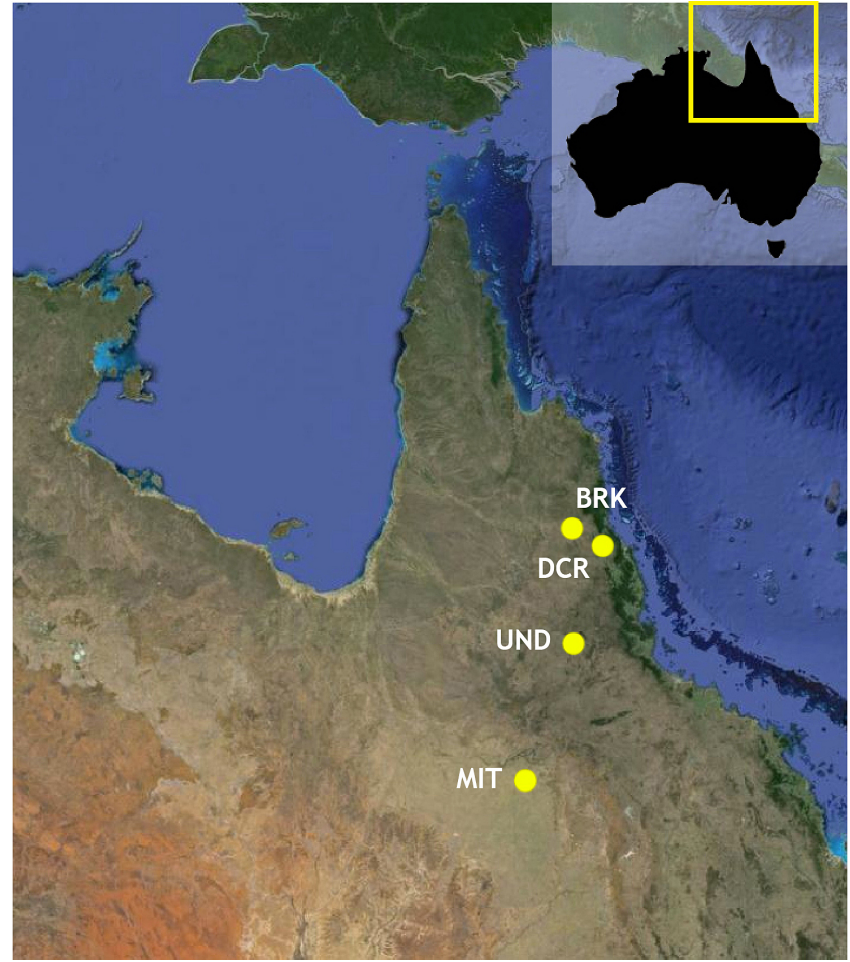

Figure 1. Geographical locations of the studied sites in northeast Australia. Source: "North East Australia" Image Landsat (2014) Google Earth.

complete combustion of $\mathrm{C}_{4}$ biomass (and hence more positive $\delta^{13} \mathrm{C}$ values for $\mathrm{CO}_{2}$ of combustion produced in savanna fires) and (ii) an additional decrease in the $\delta^{13} \mathrm{C}$ value of $\mathrm{PyC}$ remaining at the site of production, due to the preferential export of fine $\mathrm{C}_{4}$-derived PyC.

Because PyC represents a continuum of materials of various degradabilities, we focus on the quantification of the refractory PyC component (HyPyC, polyaromatic ring number $>7$; see methods for full definition), likely to have a residence time in the environment on at least the centennial scale. Indeed, an accurate determination of the abundance and stable isotope composition of the HyPyC component formed in newly produced $\mathrm{PyC}$ is critical both for achieving an im-

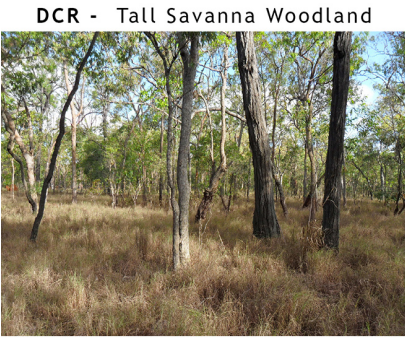

UND - Shrub-rich Savanna Woodland

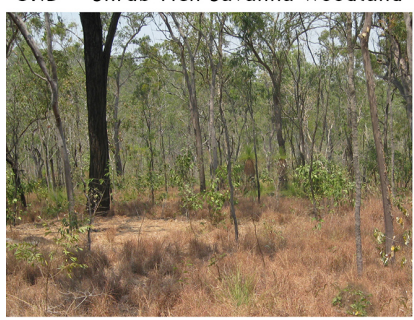

Figure 2. Characteristics and regional classification of the vegetation; the reader is referred to Torello-Raventos et al. (2013).

proved understanding of PyC dynamics, and for better interpreting records of biomass burning, climate and vegetation change in the past (Bird et al., 2015; Wurster et al., 2012). Here, we use the term PyC to describe all post-fire carbon, which in our experiments might also include non-thermally altered material.

\section{Materials and methods}

\subsection{Study sites}

The study sites were located across four contrasting savannagrassland ecosystems in Queensland (Australia). The sites extended from the drier inner region to the more humid environments located near the northeast coast (Fig. 1). The different climatic conditions prevailing at the various locations strongly influenced both the species and structural composition of these ecosystems. While there are many definitions of "savanna" (Torello-Raventos et al., 2013; Domingues et al., 2010), the functional definition used for the purpose of this study is that of a biome consisting of a continu- 


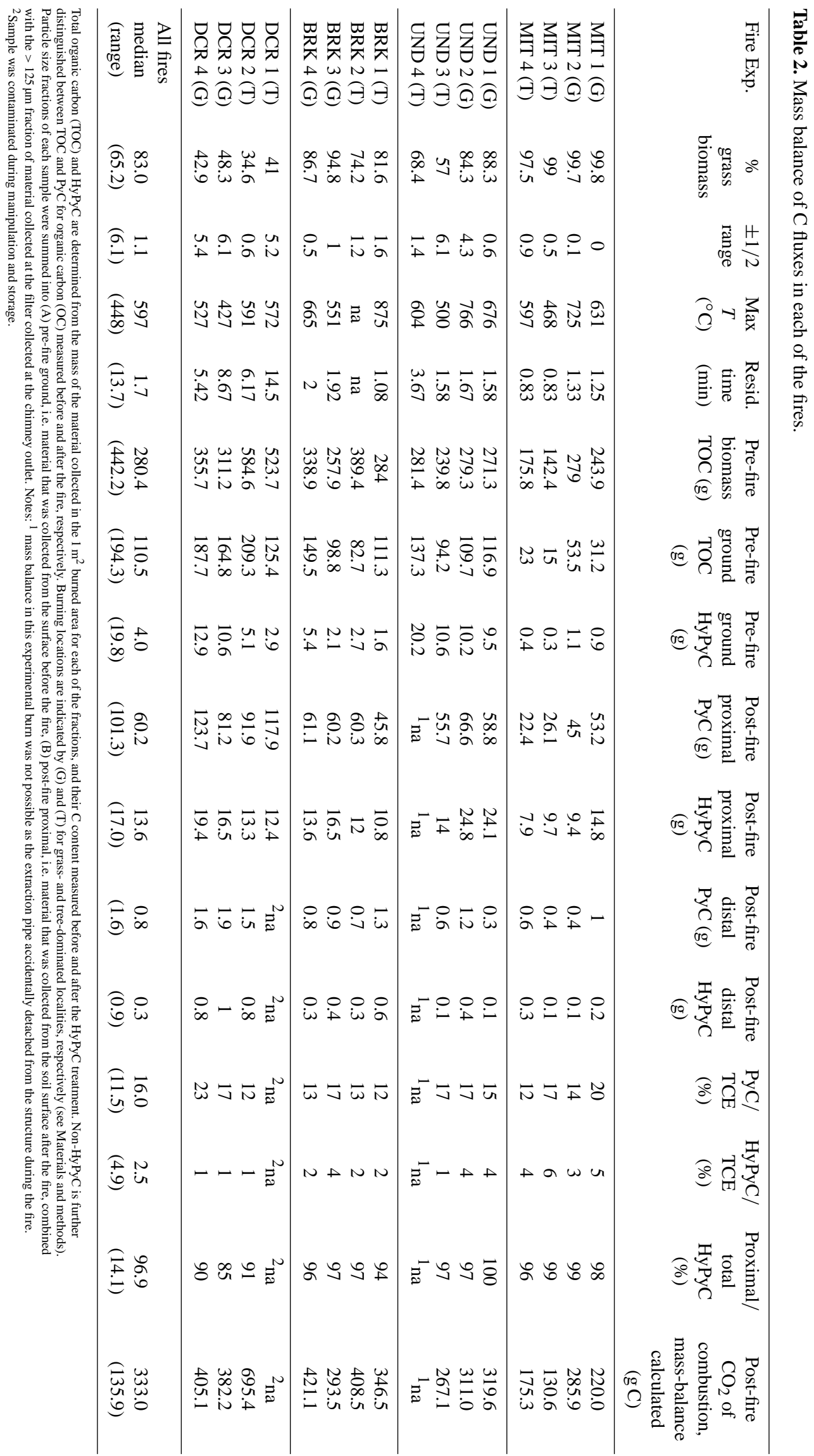


ous graminoid component coexisting with woody plants at varying densities. The regional classification of vegetation was done according to Torello-Raventos et al. (2013). We chose a wide climatic range in order to provide the experiment with a broad spectrum of woody vs. grass biomass proportions (woody is equivalent to $\mathrm{C}_{3}$ and grass to $\mathrm{C}_{4}$ ). Indeed, there was a noticeable trend both in total biomass and in the relative contribution of woody $\left(\mathrm{C}_{3}\right)$ vegetation to the total biomass across the climatic gradient (Tables 1 and 2). The transect ranged from dry Mitchell grasslands (site: MIT; $\mathrm{MAP}=435 \mathrm{~mm}$ ), characterised by $>97 \% \mathrm{C}_{4}$ grasses, to more humid tall savanna woodlands (site: DCR; $\mathrm{MAP}=2050 \mathrm{~mm}$ ). The tall savanna woodlands exhibit a larger net contribution of 50-60\% $\mathrm{C}_{3}$ vegetation to the total biomass. While $\mathrm{C}_{4}$ biomass was relatively constant across all sites, woody biomass increased with MAP (Fig. 2, Tables 1 and 2). Tree canopy cover was determined by means of sitespecific allometric equations and visual estimates (TorelloRaventos et al., 2013; Domingues et al., 2010), and ranged from $<5 \%$ for a site established in a heavily dominated grassland ecosystem (Mitchell grassland - MIT) to $55 \%$ for a tall savanna woodland located at about $20 \mathrm{~km}$ from the coast (Davies Creek National Park - DCR) (Fig. 1).

The biomass present at all fire experiment areas was mainly composed of a grass layer dominating with sparse Eucalyptus and Acacia tree seedlings with variable amounts of coarse woody debris and leaf litter. The most abundant grass species were Themeda australis, Imperata cylindrica and Heteropogon contortus.

\subsection{Field methods}

\subsubsection{Plot set-up and pre-burn sampling}

The experimental set-up was designed to provide an estimate of initial total organic C, PyC abundance and $\delta^{13} \mathrm{C}$ values, serving thus as reference to compare against post-burn samples. Burning experiments were carried out on a small scale $\left(\mathrm{m}^{2}\right)$, and were conceived to ensure the capture of all particulates to enable a full isotope mass balance. As such, the experiments were not explicitly designed to simulate all characteristics of a "natural" burn, but given the methodological issues surrounding all such techniques, the estimates of PyC production derived from this work are unlikely to be more uncertain than those obtained with other systems (see Forbes et al., 2006, for a review). Finally, we did not consider or include burnt coarse woody debris, making the reasonable assumption that most $\mathrm{PyC}$ production in savanna fires occurs close to the ground from grass, litter and shrubs (Randerson et al., 2005).

A total of four burning experiments were conducted at each of the four study areas, with specific assessments of both initial biomass and $\mathrm{PyC}$ inventory carried out before each burn. At a local scale, the abundance and $\delta^{13} \mathrm{C}$ values of litter and standing biomass are quite heterogeneous in

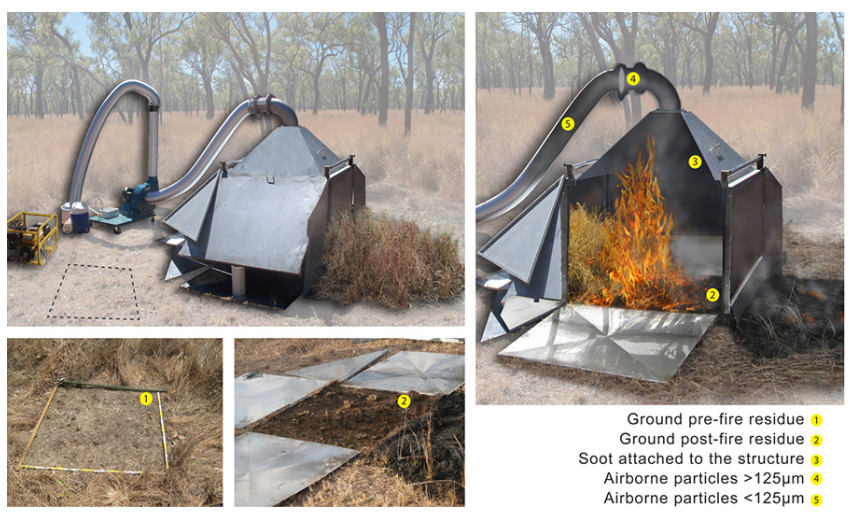

Figure 3. Schematic diagram depicting an experimental burn, with pre- and post-fire $\mathrm{C}$ pools. Initial biomass and $\mathrm{PyC}$ inventory were quantified in the near vicinity of each planned burn location by means of destructively collecting all aboveground plant material and vacuuming the soil surface from two $1 \mathrm{~m}^{2}$ census quadrats, as shown in left bottom picture.

tropical savannas. This heterogeneity is largely controlled by the distribution of trees, with lower average $\delta^{13} \mathrm{C}$ values for litter and soil $\mathrm{C}$ around trees compared to grass-dominated areas away from the influence of trees (Wynn et al., 2006; Saiz et al., 2012). Therefore, duplicate burns were conducted at locations at half crown distance from trees (Tree; $\mathrm{T}$ locations), while two additional burns were also conducted at locations remote from trees (Grass; G locations). Biomass was quantified in the near vicinity of each planned burn location by means of destructively collecting all aboveground plant material from two $1 \mathrm{~m}^{2}$ census quadrats. In order to estimate PyC lying on the soil surface, each quadrat was subsequently vacuumed using a DC 23 Motorhead vacuum cleaner (Dyson Appliances Ltd., NSW, Australia). This task was systematically performed by the same user and over the same length of time across all burning experiments to allow for inter-comparison of results. Both the biomass and the vacuumed material were stored in separate labelled plastic bags. This sampling procedure was carried out in duplicate at each burning location, which resulted in a total of $8 \times 1 \mathrm{~m}^{2}$ census quadrats being sampled per studied site (Fig. 3).

\subsubsection{Experimental burns}

Four small-scale $\left(1 \mathrm{~m}^{2}\right)$ burning experiments were conducted at each of the four study areas on sites with no recorded fires for 2 years during the late dry season of 2011. This period represents maximum fuel load available throughout the year as a result of the presence of senesced grasses that have already reached their full growth potential, and the fact that a number of tree species preferentially shed their leaves at this time. All the burns took place on days with no prior recorded rainfall for at least 2 weeks and shortly after midday, as this time generally corresponds to maximum daily temperature $(T)$. This combination of factors results in optimum condi- 
tions for the occurrence and spread of fire in these ecosystems. At the time of the burns, wind speeds were lower than $10 \mathrm{~km} \mathrm{~h}^{-1}$ in all cases, air $T$ ranged from 24.2 to $40.0^{\circ} \mathrm{C}$, and relative humidity varied from 45 to $17 \%$.

A rectangular area of approximately $3 \times 2 \mathrm{~m}$ was consistently left undisturbed at the centre of each planned fire. At this location, a purpose-built stainless steel structure was deployed to allow for both the assessment and containment of the experimental burning (Fig. 3). The final placement of the structure was chosen considering both the prevailing wind and topography with a view to strategically allocate an untouched area of vegetation $\left(>1 \mathrm{~m}^{2}\right)$ over which the fire could be ignited promoting a natural progression of the flames towards the unit. Once the structure was positioned on the ground, a $10 \mathrm{~m}$ radius buffer zone was cleared to the ground (Fig. 3).

The structure consisted of a series of leaning panels made up of lightweight stainless steel, which was several times the volume occupied by the enclosed vegetation. The leaning panels provided extra volume for an optimal collection of smoke and airborne particles, with their lower sides positioned at $15 \mathrm{~cm}$ above ground-covering metal sheets to ensure a combustion with no artificial oxygen limitation. The front panel of the unit was vertical and was open in its lower section to allow the entrance of the fire. The structure was covered by an enclosed pyramid-like chamber culminating in an outlet to a $15 \mathrm{~cm}$ diameter steel tube connected ultimately to a Romac $2042 \mathrm{~K}$ particle extraction unit $\left(0.755 \mathrm{~m}^{3} \mathrm{~s}^{-1}\right.$, 2 hp motor; Ron Mack, Perth, WA, Australia). The extractor unit was in operation during the entire course of the burn and was only disconnected after the cessation of any noticeable smouldering. A $125 \mu \mathrm{m}$ stainless steel sieve was installed in the flow path at the outlet of chamber. This mesh size was chosen to conform to standard dimensions used to differentiate between micro- and macro-charcoal in palynological studies (e.g. Blackford, 2000, and Haberle, 2005). Smaller particles contained in the airflow downstream of the first mesh were then subsampled and semi-quantitatively estimated using a particle collector and a constant flow sampling pump (Quick Take 30, SKC Inc., Eighty Four, PA, USA).

Continuous air flow monitoring was performed on a vertical pipe positioned after the extractor unit by means of a calibrated 160S series "S" type Pitot tube (Dwyer Instruments, Inc., Michigan City, IN, USA) connected to a Testo 435-4 multi-function instrument (Testo AG, Lenzkirch, Germany). Fire $T$ was recorded by means of K-type wire thermocouples connected to a data logger (Simple Logger II L642, AEMC Instruments, Dover, NH, USA) logging at $5 \mathrm{~s}$ intervals. The thermocouples were placed at the centre of the burned area at $0.02 \mathrm{~m}$ above the ground, and at the outlet of the chamber. Fire residence time was defined as the length of time that air $T$ at the chimney's outlet exceeded $100^{\circ} \mathrm{C}$. This temperature threshold accounts for most of the particulate emissions derived from a flaming front, and it is also likely to encompass the majority of smouldering emissions in grass-dominated ecosystems.

The fire was allowed to burn the biomass contained within the unit without any external intervention. After the flames self-extinguished, the leaning side panels of the structure were lowered to the ground to minimise any lateral export of the burned material. Once the unit cooled down, any remaining stubble within the enclosed burn was cut at ground level, and the same vacuum procedure employed on the two adjacent biomass quadrats was used again to determine total organic carbon (TOC) and PyC remaining on the soil surface. In order to quantify and analyse the fine soot produced during each burn, all the panels making up the structure were dismantled and thoroughly cleaned by manually brushing with a $1: 1$ water/methanol solution, with the resultant mixture stored in a glass flask. Likewise, particulates collected on the steel mesh and in the particle collector were then retrieved and carefully stored to subsequently weighed and analysed as described in the laboratory methods below.

In summary, each of the four experimental burns at each of four sites along the climate transect resulted in the field collection of the following samples:

- two biomass (vegetation quadrats)

- three ground-vacuumed (two vegetation quadrats and one burnt quadrat)

- three airborne particulate samples from the burnt quadrat (one from the steel sieve $>125 \mu \mathrm{m}$, one from the particle collector and one from the soot adhered to the metal panels).

\subsection{Laboratory methods}

\subsubsection{Initial preparations}

Biomass collected from each unburned reference quadrat was weighed, dried at $60^{\circ} \mathrm{C}$ for 5 days and re-weighed to determine fuel moisture. This material was then sorted according to either grass $\left(\mathrm{C}_{4}\right)$ or woody biomass (i.e. tree/shrub leaves, twigs; $\mathrm{C}_{3}$ ). The vacuumed material from each quadrat was also sorted, and any biomass fragments found were cleaned and added to the corresponding vegetation category (i.e. grass or woody). Thereafter these were weighed, recombined (keeping some aliquots separate for further testing) and milled. The samples vacuumed from the quadrats (both preburn and post-burn) were sieved to $2 \mathrm{~mm}$ and weighed. Separate aliquots were then size fractionated by wet sieving at 125 and $10 \mu \mathrm{m}$ to conform with the definition of microcharcoal (10-125 $\mu \mathrm{m}$; Haberle 2005). This procedure enables separate analysis of very fine $<10 \mu \mathrm{m}$ PyC that is likely to be a major component of aerosol PyC (Andreae and Merlet, 2001).

In the case of airborne particles captured in the system, the following preparation procedures were conducted: (i) the coarse airborne particles collected at the $125 \mu \mathrm{m}$ steel sieve 
positioned at the chamber outlet were flushed with a water/methanol solution $(1: 1)$ and underwent the same wet fractionation procedure as described above; (ii) the particles that passed through the steel mesh $(<125 \mu \mathrm{m})$ were wetsieved to $10 \mu \mathrm{m}$ and (iii) the soot retrieved after cleaning the structure with the water/methanol solution was placed in a rotary evaporator to remove the liquid phase, but no attempt was made to size separate this soot, as intense physical brushing may have significantly altered the "natural" particle size distribution. This fraction was subsequently added to the distal $(<125 \mu \mathrm{m})$ pool. In all cases presented above, the resultant fractions were subsequently freeze-dried, weighed and finely milled in preparation for further analyses.

\subsubsection{Hydrogen pyrolysis}

Hydrogen pyrolysis has been described in detail in a number of publications (e.g. Ascough et al., 2009; Meredith et al., 2012; Wurster et al., 2012, 2013). The technique separates $\mathrm{PyC}$ in aromatic clusters with a ring size $>7$ ( $\mathrm{HyPyC}=\mathrm{PyC}$ that is likely to be resistant to environmental degradation) from other organic $\mathrm{C}$ and has been shown to perform well in characterising $\mathrm{PyC}$ abundance in a range of environmental matrices (Meredith et al., 2012). Briefly, the solid samples were loaded with a molybdenum catalyst ( $\sim 10 \%$ of dry weight) using an aqueous/methanol solution of ammonium dioxydithiomolybdate $\left[\left(\mathrm{NH}_{4}\right)_{2} \mathrm{MoO}_{2} \mathrm{~S}_{2}\right]$. Dried, catalyst-loaded samples were placed in a reactor and pressurised with $15 \mathrm{MPa} \mathrm{H}_{2}$ under a sweep gas flow of $5 \mathrm{~L} \mathrm{~min}^{-1}$, then heated at $300^{\circ} \mathrm{C} \mathrm{min}^{-1}$ to $250^{\circ} \mathrm{C}$, then stepped at $8^{\circ} \mathrm{C} \mathrm{min}^{-1}$ to a final hold $T$ of $550^{\circ} \mathrm{C}$ for $2 \mathrm{~min}$.

Because the catalyst that is loaded undergoes weight loss during hydrogen pyrolysis, the abundance of carbon in the sample after hydrogen pyrolysis is determined relative to TOC (the mass of carbon after treatment/the mass of carbon loaded) and reported as \% HyPyC / TOC or $\% \mathrm{HyPyC} /$ sample.

\subsubsection{Carbon abundance and isotope composition}

Carbon abundance and isotope composition of samples were determined using a Costech elemental analyser (EA) fitted with a zero-blank auto-sampler coupled via a ConFloIV to a ThermoFinnigan DeltaV ${ }^{\text {PLUS }}$ mass spectrometer using continuous-flow isotope ratio mass spectrometry (EA-IRMS) at James Cook University's Cairns Analytical Unit. Stable isotope results are reported as per mil (\%o) deviations from the Vienna Pee Dee Belemnite (VPDB) reference standard scale for $\delta^{13} \mathrm{C}$ values. Precisions (SD) on internal standards were better than $\pm 0.2 \%$.

\subsection{Calculations and modelling}

Measured quantities of TOC, PyC and HyPyC in each fraction were summed into two fluxes from each of the fires: "distal" and "proximal". Proximal (likely to remain close to the site of burning) includes that collected from the surface after the fire in addition to the $>125 \mu \mathrm{m}$ fraction collected from the sieve. Distal (likely to be transported from the site of burning) includes the $<125 \mu \mathrm{m}$ fraction collected from the stainless steel sieve, as well as that collected in the particle collector attached to the pump, and the soot cleaned from the apparatus.

The percent grass biomass at each site was estimated from the mass of separated grass and woody biomass collected from two plots adjacent to the burning apparatus. An estimate of the initial isotopic composition of the biomass $\left(\delta^{13} \mathrm{C}_{\text {biomass }}\right)$ was determined by two methods. First, a bulk sample of the biomass from the two vegetation plots was homogenised and its $\delta^{13} \mathrm{C}$ value measured. Second, the separately summed masses of grass and woody vegetation were used to estimate the bulk isotopic composition, assuming specific values for $\mathrm{C}_{3}$ woody biomass $\left(-27.2 \%\right.$ ) and for $\mathrm{C}_{4}$ grass biomass (-13.1\%o; values from Cerling et al., 1997). The estimated percent grass biomass values produced by these two methods agreed (linear regression $r^{2}=0.88$ ). The average of the two estimates is used as the central tendency, while the range of values is used as an error in these estimates. The carbon isotopic composition of $\mathrm{CO}_{2}$ and other trace gases produced by combustion for each of the fires was calculated by mass balance using the amount and isotopic composition of initial biomass and of the residual products of combustion (note that this mass difference calculation of $\mathrm{CO}_{2}$ likely includes other carbonaceous trace gases such as $\mathrm{CO}$ and $\mathrm{CH}_{4}$ ).

The value of SIDE can be expressed as an "isodisequilibrium forcing coefficient" following the terminology of Alden et al. (2010), which is the difference between the $\delta^{13} \mathrm{C}$ values of forward and reverse fluxes between two reservoirs. The values of SIDE were calculated for each of the component fluxes from the fires as the difference between the $\delta^{13} \mathrm{C}$ value of the flux $\left(\delta^{13} \mathrm{C}_{\text {flux }}\right.$, for example, the distal HyPyC component, $\delta^{13} \mathrm{C}_{\text {flux }}=\delta^{13} \mathrm{C}_{\text {distal HyPyC }}$ ) and the initial $\delta^{13} \mathrm{C}$ value of the biomass $\left(\delta^{13} \mathrm{C}_{\text {biomass }}\right)$. The values of SIDE from each of the four fluxes were regressed with respect to the estimate of percent grass biomass using the Matlab curve-fitting toolbox with a power function. The significance of the power law curve fit was calculated as a $p$ value, which describes the probability, with an $F$ test, that the relationship is a better estimate than simply the mean value of SIDE. Confidence intervals for the curve fit equations were calculated at $p=0.9$. The distribution of residuals was tested for normality with a Jarque-Bera test.

The savanna isotopic disequilibrium flux $\left(D_{\mathrm{SIDE}_{-} \mathrm{CO}_{2}}=F_{\text {bur }}\left(\mathrm{SIDE}_{\mathrm{CO}_{2}}\right)\right.$, where $F_{\text {bur }}$ is the flux of $\mathrm{C}$ from annual biomass burning) was calculated for global savanna environments using an estimate of the fraction of $\mathrm{C}_{4}$ photosynthesis from Still et al. (2003). The calculated $F_{\text {bur }}$ value for savannas was averaged over the period from 1997 to 2011 using the Global Fire Emissions Database (GFED; http://globalfiredata.org; van der Werf et al., 2010), clipped 
(a)

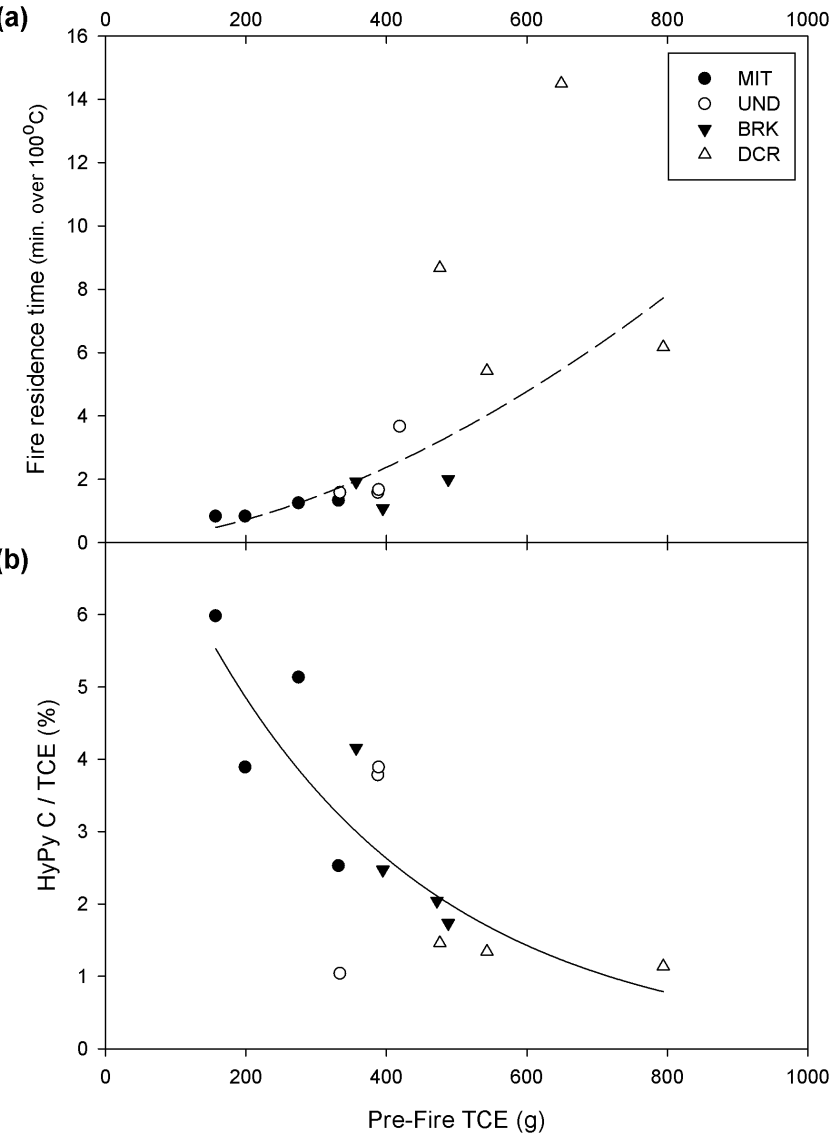

Figure 4. (a) Relationship between total carbon exposed (TCE) and fire residence time. The regression (dashed line) takes the following form: minutes over $100^{\circ} \mathrm{C}=8 \times 10^{-5}$ (TCE) $)^{1.719} ; r^{2}$ 0.66; $p<0.05$; BIC (Bayesian information criterion) $3.47 ; n=14$. (b) Relationship between TCE and the proportion of pyrogenic carbon produced (HyPyC) relative to TCE. The regression (solid black line) takes the following form: HyPyC / TCE $(\%)=48.6-$ 30.9 (TCE) $^{0.066} ; r^{2} 0.61 ; p<0.05$; BIC $6.27 ; n=14$. Different symbols group the individual burning experiments into the different ecosystems shown in Fig. 2; individual data are presented in Table 2.

to the area where $\mathrm{C}_{4}$ grasses $>1 \%$ (Still et al., 2003). The global distribution of the isotopic disequilibrium flux was calculated and plotted using Generic Mapping Tools (GMT; Wessel et al., 2013).

\section{Results}

\subsection{Production of PyC during savanna burning}

The total carbon exposed (TCE) to combustion showed a discernable pattern across the precipitation gradient, with higher potentially combustible $\mathrm{C}$ in standing biomass and surface litter at the more humid sites (Table 2, Fig. 2). The median (range) production of $\mathrm{PyC}$ and $\mathrm{HyPyC}$ was 16.0 (11.5) \% and 2.5 (4.9) \% of TCE across all experimental burns (Table 2).

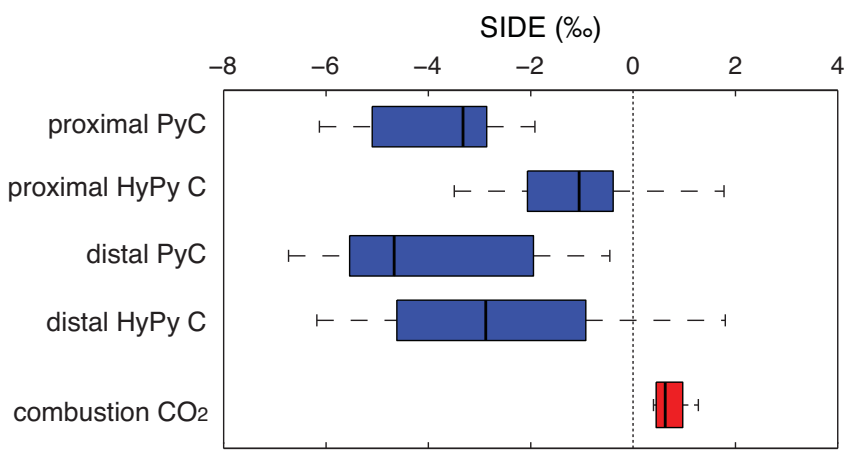

Figure 5. Box and whisker plot of isotopic disequilibrium values (SIDE $=\delta^{13} \mathrm{C}_{\text {flux }}-\delta^{13} \mathrm{C}_{\text {pool }}$ ) for proximal and distal fluxes of $\mathrm{PyC}$ and $\mathrm{HyPyC}$, and combustion $\mathrm{CO}_{2}$ calculated by mass balance ( $n=16$ for proximal components; $n=15$ for distal components, $n=14$ for combustion $\mathrm{CO}_{2}$ ). Line at centre of box represents the sample median, box represents 25 th and 75 th percentiles and whiskers represent range.

Similarly, the amount of total carbon combusted (TCC) defined as the difference between TCE and post-fire carbon was used to calculate combustion completeness (described as TCC relative to TCE), and whose median (range) for all fires was $84.0(11.5) \%$. The median (range) amount of HyPyC in the proximal component $(>125 \mu \mathrm{m})$ of the flux from the fires was 96.9 (14.1)\% of the total HyPyC flux across all experimental burns. Fire residence time, defined as time over which air $T$ at the chimney's outlet exceeded $100^{\circ} \mathrm{C}$, increased with TCE (Fig. 4), and thus with the proportion of woody biomass (Table 2). The proportion of TCE converted to HyPyC significantly decreased with initial TCE, and thus decreased with the proportion of woody biomass (Fig. 4; Table 2).

\subsection{Isotopic disequilibria of proximal and distal fluxes of PyC and HyPyC}

The values of SIDE were computed from $\delta^{13} \mathrm{C}$ values shown in Table 3. When considering the $\mathrm{PyC}$ pool, the median (range) SIDE value of proximal PyC (SIDE proximal $-\mathrm{PyC}$; -3.3 (4.2)\%; where SIDE $=\delta^{13} C_{\text {flux }}-\delta^{13} C_{\text {biomass }}$, with superscripts proximal or distal and $\mathrm{PyC}$ or HyPyC relevant to the flux) was not significantly different from the median (range) SIDE value of distal PyC (SIDE distal $-\mathrm{PyC}$; -4.7 (6.3)\%o; $p=0.737$, Mann-Whitney $U$ test; Fig. 5). However, the median (range) SIDE value of proximal

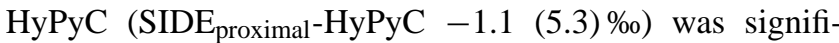
cantly different from the median (range) SIDE value of distal HyPyC (SIDE distal $-\mathrm{HyPyC} ;-2.9(8.0) \% ; p=0.024$; Fig. 5). Comparing the two proximal fluxes, the median value of $\mathrm{SIDE}_{\text {proximal }}-\mathrm{PyC}$ was significantly different from the me-

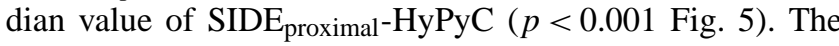
median value of $\mathrm{SIDE}_{\mathrm{distal}}-\mathrm{PyC}$ was not significantly different from the median value of $\operatorname{SIDE}_{\text {distal }}-\mathrm{HyPyC}(p=0.245$; 
Table 3. Stable isotopic composition $\left(\delta^{13} \mathrm{C}\right.$ values) of $\mathrm{C}$ fluxes from each of the fires; standard errors of the means are shown in parentheses. Explanations for the different fractions are as in Table 2.

\begin{tabular}{|c|c|c|c|c|c|c|c|c|c|c|}
\hline Fire Exp. & $\begin{array}{c}\text { Pre-fire } \\
\text { biomass } \\
\text { TOC } \\
\delta^{13} \mathrm{C} \\
(\% \circ)\end{array}$ & $\begin{array}{c}{ }^{\text {a Pre-fire }} \\
\text { biomass } \\
\text { mass-based } \\
\delta^{13} \mathrm{C} \\
(\% \circ)\end{array}$ & $\begin{array}{c}\text { Pre-fire } \\
\text { ground } \\
\text { TOC } \\
\delta^{13} \mathrm{C} \\
(\% o)\end{array}$ & $\begin{array}{c}{ }^{\mathrm{b}} \text { Pre-fire } \\
\text { measured } \\
\text { TCE } \\
\delta^{13} \mathrm{C} \\
(\% o)\end{array}$ & $\begin{array}{c}\text { Pre-fire } \\
\text { ground } \\
\text { HyPyC } \\
\delta^{13} \mathrm{C} \\
(\% o)\end{array}$ & $\begin{array}{c}\text { Post-fire } \\
\text { proximal } \\
\text { PyC } \\
\delta^{13} \mathrm{C} \\
(\% o)\end{array}$ & $\begin{array}{c}\text { Post-fire } \\
\text { proximal } \\
\text { HyPyC } \\
\delta^{13} \mathrm{C} \\
(\% o)\end{array}$ & $\begin{array}{c}\text { Post-fire } \\
\text { distal } \\
\text { PyC } \\
\delta^{13} \mathrm{C} \\
(\% o)\end{array}$ & $\begin{array}{c}\text { Post-fire } \\
\text { distal } \\
\text { HyPyC } \\
\delta^{13} \mathrm{C} \\
(\% o)\end{array}$ & $\begin{array}{c}\text { Post-fire } \\
\mathrm{CO}_{2} \text { of } \\
\text { combustion, } \\
\text { mass-balance } \\
\text { calculated }(\% o)\end{array}$ \\
\hline MIT 1 (G) & -14.5 & -13.2 & -16.7 & -14.8 & -13.9 & -16.0 & -14.8 & -20.7 & -15.9 & -14.4 \\
\hline MIT $2(G)$ & -14.3 & -13.2 & -16.6 & -14.7 & -15.2 & -16.7 & -16.4 & -20.4 & -20.1 & -14.3 \\
\hline MIT $3(\mathrm{~T})$ & -14.4 & -13.3 & -16.9 & -14.7 & -15.8 & -17.0 & -15.5 & -20.5 & -20.1 & -14.2 \\
\hline MIT $4(\mathrm{~T})$ & -14.7 & -13.5 & -18.1 & -15.1 & -16.2 & -17.3 & -15.5 & -19.7 & -19.6 & -14.8 \\
\hline UND 1 (G) & -14.4 & -14.8 & -18.9 & -15.7 & -15.8 & -18.7 & -17.5 & -20.8 & -19.6 & -15.2 \\
\hline UND $2(G)$ & -15.1 & -15.3 & -19.1 & -16.2 & -15.9 & -17.8 & -16.7 & -17.6 & -16.9 & -15.8 \\
\hline UND $3(\mathrm{~T})$ & -18.9 & -19.2 & -23.1 & -20.2 & -17.9 & -21.6 & -17.9 & -20.8 & -17.9 & -19.9 \\
\hline UND $4(\mathrm{~T})$ & -15.7 & -17.6 & -23.9 & -18.4 & -17.9 & -23.2 & -17.7 & -20.2 & -18.8 & ${ }^{c}$ na \\
\hline BRK 1 (T) & -14.8 & -15.7 & -21.9 & -16.8 & -21.2 & -20.7 & -16.5 & -20.0 & -19.1 & -16.2 \\
\hline BRK 2 (T) & -16.3 & -16.7 & -18.0 & -16.6 & -22.3 & -22.6 & -18.5 & -21.3 & -19.8 & -15.7 \\
\hline BRK $3(\mathrm{G})$ & -13.1 & -13.9 & -18.0 & -14.4 & -20.0 & -20.3 & -16.4 & -18.8 & -18.8 & -13.2 \\
\hline BRK 4 (G) & -14.1 & -15.0 & -21.5 & -16.3 & -21.9 & -20.7 & -16.8 & -20.6 & -19.8 & -15.6 \\
\hline DCR $1(\mathrm{~T})$ & -22.2 & -21.4 & -25.4 & -22.8 & -24.3 & -25.7 & -23.0 & $\mathrm{~d}_{\mathrm{na}}$ & $\mathrm{d}_{\mathrm{na}}$ & $\mathrm{d}_{\mathrm{na}}$ \\
\hline DCR $2(\mathrm{~T})$ & -22.2 & -22.3 & -25.9 & -23.1 & -25.4 & -25.7 & -22.9 & -23.3 & -23.5 & -22.8 \\
\hline DCR $3(\mathrm{G})$ & -17.8 & -20.4 & -25.7 & -20.4 & -24.7 & -25.6 & -23.9 & -23.4 & -23.1 & -19.3 \\
\hline DCR 4 (G) & -21.3 & -21.1 & -25.6 & -22.7 & -25.4 & -25.2 & -22.4 & -22.4 & -22.1 & -22.0 \\
\hline All Fires & $-15.0(9.1)$ & $-15.5(9.1)$ & $-20.0(9.0)$ & $-16.5(8.7)$ & $-19.0(11.5)$ & $-20.7(9.7)$ & $-17.2(9.1)$ & $-20.6(5.8)$ & $-19.6(7.6)$ & $-15.7(9.6)$ \\
\hline
\end{tabular}

Notes: a estimated carbon isotopic composition based on the mass of woody and grass biomass, assuming specific values for $\mathrm{C}_{3}$ woody biomass $\left(-27.2 \%\right.$ ) and for $\mathrm{C}_{4}$ grass biomass $(-13.1 \%$ ); values from Cerling et al. (1997). ${ }^{\mathrm{b}}$ TCE: total carbon exposed, mass-weighted isotopic composition of pre-fire biomass and ground TOC. ${ }^{\mathrm{c}}$ Mass balance in this experimental burn was not possible as the extraction pipe accidentally detached from the structure during the fire. ${ }^{\mathrm{d}}$ Sample was contaminated during manipulation and storage.

Fig. 5). The median (range) SIDE value of $\mathrm{CO}_{2}$ of combustion $\left(\mathrm{SIDE}_{\mathrm{CO}_{2}}\right)$ was $0.61 \%$ (0.88\%o) (Fig. 5).

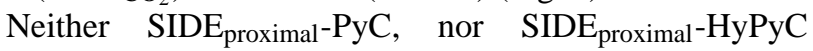
shows a significant relationship to the initial proportion of $\mathrm{C}_{4}$ biomass ( $p=0.50$ and $p=0.44$, respectively;

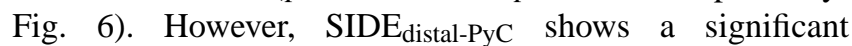
power-law relationship to the initial proportion of $\mathrm{C}_{4}$ biomass $\left(\mathrm{SIDE}_{\mathrm{distal}} \mathrm{PyC}=-1.068 \times 10^{-5}(\% \text { grass })^{2.862}\right.$ $\left.0.661 ; r^{2}=0.789 ; p=0.007\right)$, with values decreasing towards the $\mathrm{C}_{4}$-dominated end of the vegetation gradient (Fig. 6). Similarly, SIDE distal $-\mathrm{HyPyC}$ was positively correlated with the initial proportion of $\mathrm{C}_{4}$ biomass $\left(\mathrm{SIDE}_{\mathrm{distal}}-\mathrm{HyPyC}=-3.243 \times 10^{-7} \quad(\% \text { grass })^{3.589}-0.298\right.$; $\left.r^{2}=0.577 ; p=0.094\right)$. $\mathrm{SIDE}_{\mathrm{combustion}-\mathrm{CO}_{2}}$ showed no significant relationship to the initial proportion of $\mathrm{C}_{4}$ biomass $(p=0.99)$.

\section{Discussion}

\subsection{Production of PyC across contrasting savanna environments}

The proportion of biomass converted to $\mathrm{PyC}$ and $\mathrm{HyPyC}$ during the experimental burns varied across the range of savannas studied (Table 2, Fig. 4). The median PyC / TCE conversion rate of $16.0 \%$ is in the upper range of values reported in previous studies, although those could have underestimated actual PyC conversion rates due to a combination of factors, which include the use of analytical techniques focusing only on recalcitrant PyC components, the non-inclusion of all $\mathrm{PyC}$ materials being produced, and the choice of experimental fires not being representative of typical wildfire conditions (Santín et al., 2015). However, the observation that the relative amount of HyPyC produced in grass-dominated savannas was larger than in woody-biomass-dominated savannas runs counter to our initial assumption that anticipated that more woody biomass would promote the production of proportionally more HyPyC. Longer fire residence times were positively correlated with greater TCE, which resulted in less $\mathrm{HyPyC}$ being formed due to the opportunity for more complete combustion (Fig. 4). Indeed, incomplete combustion of biomass can mainly be ascribed to the combined effects of low combustion $T$, short fire residence times and an overall lack of available oxygen (Loo and Koppejan, 2002).

Typically, low fire residence time is reported for fastmoving fires characteristic of landscapes with abundant fine fuel, such as savannas (Hartford and Frandsen, 1992; Wright and Bailey, 1982). While fire residence time was shorter for the grass-dominated sites, maximum $T$ was quite comparable across all the studied sites (Table 2), and agrees well with results reported for savanna fires elsewhere (Miranda et al., 1993; Trollope, 1984). Therefore, the short-lived fires occurring in grass-dominated ecosystems may result in the production of proportionally more HyPyC (Table 2, Fig. 4). The median (range) production of $\mathrm{HyPyC}$ as a proportion of both TCE and TCC were 2.5 (4.9) and 2.9 (5.9) \%, respec- 


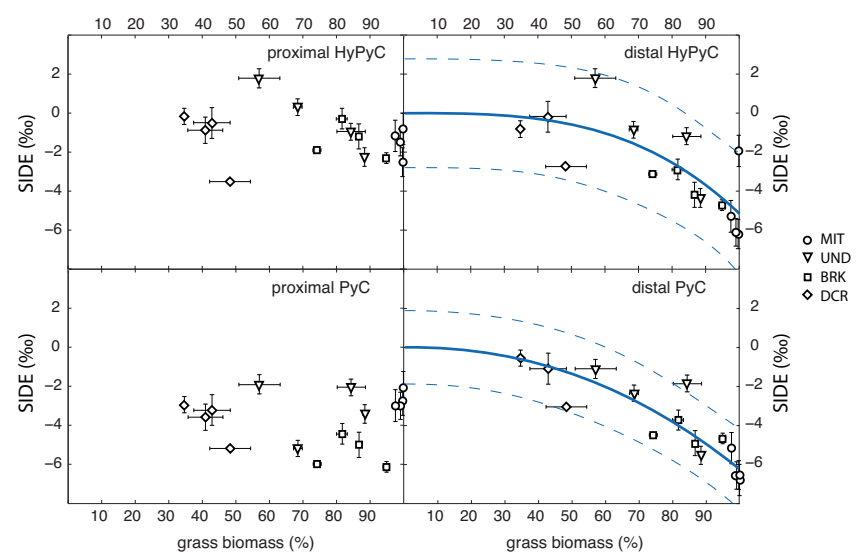

Figure 6. Relationship of isotopic disequilibrium values (SIDE $=\delta^{13} \mathrm{C}_{\mathrm{flux}}-\delta^{13} \mathrm{C}_{\mathrm{pool}}$ ) to the initial proportion of grass biomass (percentage by mass). Error bars of percentage grass biomass represent the range of values measured from two $1 \mathrm{~m}^{2}$ quadrats. Error bars of $\Delta \delta{ }^{13} \mathrm{C}$ represent values calculated using the difference from the isotopic composition of standing biomass $\left(\delta^{13} \mathrm{C}_{\text {pool }}\right)$ as determined by one of two methods: (1) measurement of the bulk $\mathrm{C}$ isotopic composition of biomass collected from the two quadrats and (2) estimated carbon isotopic composition based on the mass of woody and grass biomass, assuming specific values for $\mathrm{C}_{3}$ woody biomass $\left(-27.2 \%\right.$ ) and for $\mathrm{C}_{4}$ grass biomass ( $-13.1 \%$; values from Cerling et al., 1997). Solid line shows best curve fit of the power-law equation, with dashed lines representing $90 \%$ confidence intervals. $n=16$ for proximal components; $n=15$ for distal components. Residuals of the power law fits to the distal $\mathrm{HyPyC}$ and distal $\mathrm{PyC}$ data showed a normal distribution (Jarque-Bera), with mean residual SIDE values of -0.03 and $-0.02 \%$, respectively.

tively. These values compare well with estimates of "black carbon" (charcoal) production for savanna and grassland fires reviewed by Forbes et al. (2006).

\subsection{Allocation of $\mathrm{PyC}$ produced during savanna fires}

In order to better constrain the global PyC cycle, there is an obvious need for a deeper understanding of the factors controlling formation, translocation and mineralisation of $\mathrm{PyC}$ and its recalcitrant compounds, represented here by HyPyC (Bird et al., 2015; Conedera et al., 2009; Zimmermann et al., 2012). In this context, the partitioning of PyC between the proximal and distal fluxes may have a strong influence on preservation potential (Thevenon et al., 2010). Blackford (2000) reports an order of magnitude decrease in the percentage of charred particles $>125 \mu \mathrm{m}$ observed at just $7 \mathrm{~m}$ from a recently burned area. In contrast, smaller-sized particles can be transported by wind up to thousands of kilometres, with this range largely depending on the particle size, height of the convection column and environmental conditions (Clark, 1988). The total amount of HyPyC contained in both fluxes varied across the burning experiments, but with most of the HyPyC in the proximal flux in all cases.
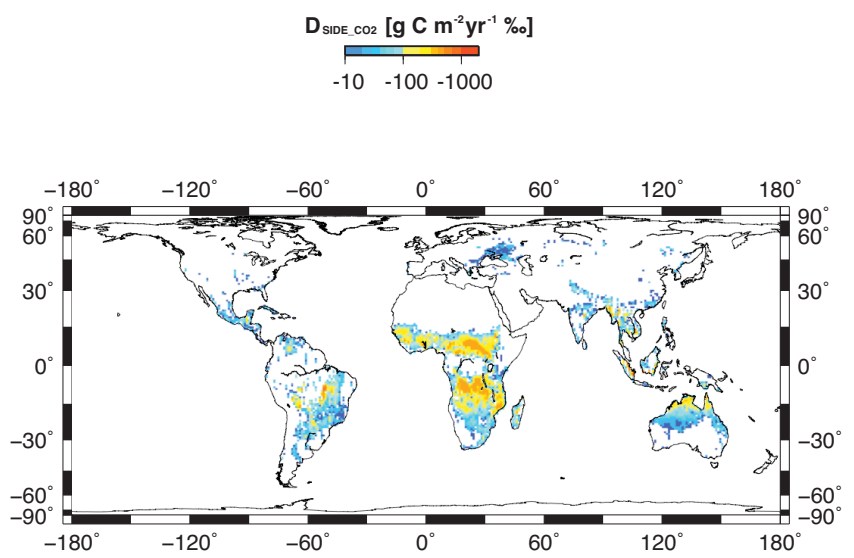

Figure 7. Global map of savanna isotope "disequilibrium flux" (following terminology of Alden et al. (2010) $\left.D_{\mathrm{SIDE}} \mathrm{CO}_{2}=\mathrm{SIDE}_{\mathrm{CO}_{2}} \times F_{\text {bur }}\right)$ of the flux of $\mathrm{CO}_{2}$ of combustion. The value of $\mathrm{SIDE}_{\mathrm{CO}_{2}}$ used is $0.61 \%$. $F_{\text {bur-savanna is }}$ the mean annual flux of $\mathrm{CO}_{2}$ from savanna fires, averaged over the period from 1997 to 2011 using the Global Fire Emissions Database (GFED; http://globalfiredata.org; van der Werf et al., 2010), clipped to the area where $\mathrm{C}_{4}$ grasses $>1 \%$ (Still et al., 2003), with an estimated fraction of combusted $\mathrm{CO}_{2}$ of 0.83 (estimated from Table 2).

The proportion of HyPyC in the proximal flux was very large in grass-dominated savannas ( $>96 \%$ of total HyPyC at MIT), compared to the proportion of HyPyC in the proximal flux in woody-biomass-dominated savannas (86-91\% of total HyPyC at DCR). This also suggests that longer fire residence times result in not only a more complete combustion of biomass; they may also promote more effective comminution and volatilisation of fuel into fine particles and gases. Such an effect was also observed by Kuhlbusch et al. (1996), who found burning experiments with the highest fuel loads showed the highest degree of $\mathrm{C}$ volatilisation.

\subsection{Savanna isotope disequilibrium effects (SIDE)}

In general, the calculated SIDE values are consistent with relative ${ }^{13} \mathrm{C}$-depletion of $\mathrm{PyC}$ produced during savanna fires (Krull et al., 2003), with some significant distinctions between proximal and distal fluxes, as well as between the $\mathrm{PyC}$ and the HyPyC fluxes (Fig. 6). A relative ${ }^{13} \mathrm{C}$-depletion is more consistently observed for the proximal PyC, with $\delta^{13} \mathrm{C}$ values always lower than the original biomass. The $\delta^{13} \mathrm{C}$ values of the proximal flux of HyPyC were also generally lower, with the exception of two fires (UND 3-4; Table 3, Fig. 5). The distal flux of $\mathrm{PyC}$ also had lower $\delta^{13} \mathrm{C}$ values than the precursor biomass. The observation that $\mathrm{PyC}$ is relatively ${ }^{13} \mathrm{C}$-depleted with respect to the original biomass across all sites supports the hypothesis that, where woody $\left(\mathrm{C}_{3}\right)$ and grass $\left(\mathrm{C}_{4}\right)$ biomass are both present, the $\left(\mathrm{C}_{4}\right)$ grass biomass is preferentially combusted relative to $\left(\mathrm{C}_{3}\right)$ woody material, leaving PyC from woody biomass to contribute dispropor- 
tionately to the $\mathrm{PyC}$ flux (i.e. $\mathrm{SIDE}_{\mathrm{PyC}}$ values are negative). Also, because the $\delta^{13} \mathrm{C}$ values of $\mathrm{PyC}$ are relatively ${ }^{13} \mathrm{C}$ depleted with respect to original biomass, mass balance dictates that the $\delta^{13} \mathrm{C}$ values of $\mathrm{CO}_{2}$ of combustion are relatively ${ }^{13} \mathrm{C}$-enriched with respect to original biomass (i.e. $\mathrm{SIDE}_{\mathrm{CO}_{2}}$ values are positive; Fig. 5).

This differential fractionation between the products of combustion and original biomass may represent a significant contribution to the global carbon isotope disequilibrium terms used in ${ }^{13} \mathrm{C}$ double deconvolution models of atmospheric $\mathrm{CO}_{2}$ (Alden et al., 2010; Ciais et al., 2005; Enting et al., 1995). The isodisequilibrium forcing coefficient for biomass burning, here referred to as $I_{\text {bur }}$, is defined as the difference in the $\Delta^{13} \mathrm{C}$ value of $\mathrm{CO}_{2}$ produced by biomass burning and the $\Delta^{13} \mathrm{C}$ value of $\mathrm{CO}_{2}$ into biomass regrown after burning:

$I_{\text {bur }}=\left(\delta^{13} C_{\mathrm{CO} 2 \_ \text {bur }}-\delta^{13} \mathrm{C}_{\mathrm{CO} 2 \_ \text {regrow_bur }}\right)$,

while the disequilibrium associated with this term ( $D_{\text {bur }}$ of Ciais et al. (2005) is

$D_{\text {bur }}=F_{\text {bur }}\left(I_{\text {bur }}\right)$,

where $F_{\text {bur }}$ is the atmospheric source flux of $\mathrm{CO}_{2}$ due to biomass burning.

However, as used in double deconvolution mass balance models, $I_{\text {bur }}$ assumes no isotopic fractionation associated with combustion, i.e. that the $\delta^{13} \mathrm{C}$ value of $\mathrm{CO}_{2}$ of combustion $\left(\delta^{13} \mathrm{C}_{\mathrm{CO} 2}\right.$ bur $)$ is equal to that of biomass burnt $\left(\delta^{13} \mathrm{C}_{\text {biomass-bur }}\right)$. Because our results show that $\mathrm{CO}_{2}$ of combustion is ${ }^{13} \mathrm{C}$-enriched with respect to biomass burnt (by a $\mathrm{SIDE}_{\mathrm{CO}_{2}}$ value of about $0.6 \%$ ), we can explicitly account for this during the calculation of $I_{\text {bur }}$ :

$$
I_{\text {bur* }}=\left(\delta^{13} \mathrm{C}_{\text {biomass_bur }}+\mathrm{SIDE}_{\mathrm{CO}_{2}-\delta} \delta^{13} \mathrm{C}_{\mathrm{CO}_{2} \_ \text {regrow_bur }}\right) \text {. }
$$

An asterisk is used to indicate that the term accounts for fractionation during combustion. The total burning disequilibrium becomes

$$
\begin{aligned}
D_{\text {bur* }}= & F_{\text {bur }}\left(\delta^{13} \mathrm{C}_{\text {biomass_bur }}-\delta^{13} \mathrm{C}_{\text {biomass_regrow_bur }}\right) \\
& +F_{\text {bur }}\left(\mathrm{SIDE}_{\mathrm{CO}_{2}}\right), \\
D_{\text {bur* }}= & D_{\text {bur }}+D_{\mathrm{SIDE}_{-} \mathrm{CO}_{2} .} .
\end{aligned}
$$

The first term is the disequilibrium as calculated by Ciais et al. (2005), and assumes no fractionation associated with combustion. The second term explicitly accounts for $\mathrm{SIDE}_{\mathrm{CO}_{2}}$ associated with differential combustion of $\mathrm{C}_{3}$ and $\mathrm{C}_{4}$ biomass. The global value of $D_{\mathrm{SIDE}} \mathrm{CO}_{2}$ is estimated in Fig. 7 to have a global sum of about $0.75 \mathrm{Gt} \mathrm{Cyr}^{-1} \%$. This value may be an upper bound for $D_{\text {SIDE }}$ because some of the ${ }^{13} \mathrm{C}$-depleted $\mathrm{PyC}$ may be mineralised after the fire, as was observed by Zimmermann et al. (2012).

Figure 5 shows that in both the proximal and distal fluxes, the significance of SIDE during burning is more pronounced when considering the PyC produced by the fires than when considering the HyPyC component alone. The observed patterns highlight the importance of SIDE for the more labile or semi-labile components of the $\mathrm{PyC}$ flux, into which $\mathrm{C}_{4}$ derived PyC may be preferentially partitioned. However, the significance of SIDE is less pronounced in the more stable pool of PyC flux, into which $\mathrm{C}_{3}$-derived $\mathrm{PyC}$ may be preferentially partitioned.

We used particle size separations of PyC fluxes to test the hypothesis that $\mathrm{PyC}$ remaining near the site of production shows a more pronounced SIDE due to preferential export of $\mathrm{C}_{4}$-derived $\mathrm{PyC}$ in the finer particle size fractions. While no significant trends are observed for the proximal fluxes of PyC (either the total or HyPyC components), the relationship is significant for both distal $\mathrm{PyC}$ and for distal HyPyC (Fig. 6). These observations indicate that in grassdominated environments, the preferential export of fine particle size fractions is likely to be dominated by low $\delta^{13} \mathrm{C}$ components of PyC. Thus, the SIDE is more pronounced in grassdominated fires either because (a) the small amount of $\mathrm{C}_{3}$ derived PyC flux in these systems is preferentially exported in the fine (soot) fraction of the distal component or (b) compounds with low $\delta^{13} \mathrm{C}$ values are preferentially exported to the fine fraction (Das et al., 2010; Krull et al., 2003). Krull et al. (2003) attributed this effect to the occlusion of protected ${ }^{13} \mathrm{C}$-depleted compounds in phytoliths of $\mathrm{C}_{4}$ grasses, and our results further suggest that ${ }^{13} \mathrm{C}$-depleted compounds (e.g. lipids, lignins and phytoliths) may be preserved in $\mathrm{PyC}$ (O'Malley et al., 1997), as they are preferentially exported as highly condensed aromatic structures in the fine soot components of natural fires. Another significant contributor to SIDE may also be the plant methoxyl pool, which is extremely depleted in ${ }^{13} \mathrm{C}(\sim-29 \%$ o in leaves relative to bulk biomass $)$ and comprises about $2.5 \%$ of plant biomass (Keppler et al., 2004). Moreover, the same authors report that the fractionation associated with the methoxyl groups may be further enhanced during their conversion to volatile compounds (i.e. through burning), which could also contribute to the low $\delta^{13} \mathrm{C}$ values we observed in the soot fraction. Nonetheless, we cannot rule out the possibility that a significant proportion of this soot component may derive from the small amount of $\mathrm{C}_{3}$ biomass present, even in $\mathrm{C}_{4}$-dominated ecosystems.

The small-scale experimental set-up used here did not consider coarse woody debris (CWD), which is common in most savanna environments and may burn along with other biomass on the ground. As this material is exclusively composed of $\mathrm{C}_{3}$ biomass, the inclusion of $\mathrm{PyC}$ from CWD would likely increase the contribution of proximal $\mathrm{PyC}$ to the total flux, further enhancing the SIDE on SOC $\delta^{13} \mathrm{C}$ (Bird and Pousai, 1997; Wynn and Bird, 2008).

\subsection{Implications of SIDE}

The calculation of the global SIDE disequilibrium flux (Fig. 7) reinforces the conclusion that the effects of SIDE 
during savanna burning are most pronounced in grassdominated savannas, where $\mathrm{C}_{4}$ plants are the most significant fraction of biomass. Scaling these trends up to the global scale indicates a significant SIDE forcing for the savanna biome, which may contribute to a ${ }^{13} \mathrm{C}$ disequilibrium flux on the order of $0.75 \mathrm{Gt} \mathrm{C} \mathrm{yr}^{-1} \%$, a value which is of significant magnitude in comparison to other ${ }^{13} \mathrm{C}$ disequilibrium fluxes used in mass balance models (Ciais et al., 2005). This ${ }^{13} \mathrm{C}$ disequilibrium flux $\left(D_{\mathrm{SIDE}_{-} \mathrm{CO}_{2}}\right)$ accounts for isotope fractionation associated with differential combustion of $\mathrm{C}_{3}$ and $\mathrm{C}_{4}$ biomass, which is otherwise not explicitly accounted for, and would contribute to the total biomass burning isotopic disequilibrium ( $\left.D_{\text {bur }}\right)$ caused by regrowth of ecosystems after fires (1.66 Gt C yr ${ }^{-1} \%$; Ciais et al.; 2005).

Because grass-dominated savannas show high SIDE for $\mathrm{PyC}$, the implication is that SOC in savannas with frequent grass-dominated fires will become increasingly ${ }^{13} \mathrm{C}$ depleted, as the stable components of $\mathrm{PyC}$ accumulate in the soil over time. This observation is consistent with studies of SOC at large spatial scales, for example, where grassdominated Mitchell grasslands show lower $\delta^{13} \mathrm{C}$ values of surface SOC (ca. $-16 \%$ ) than is typical of $\mathrm{C}_{4}$ biomass (ca. $-12 \%$ ) (Bird and Pousai, 1997; Wynn and Bird, 2008), and agrees well with findings by Dümig et al. (2013) which indicate both the presence of charred grass residues and accumulation of alkyl $\mathrm{C}$ in soil fractions as the most likely contributors to the observed decreasing $\delta^{13} \mathrm{C}$ values from grass biomass to $\mathrm{C}_{4}$-derived surface SOC. Such a conclusion has implications for interpretation of palaeo-records derived from ancient SOC or its by-products in sedimentary records, which may be biased towards ${ }^{13} \mathrm{C}$-depleted values by this SIDE during savanna burning.

\section{Conclusions}

The production of PyC and HyPyC was quantified in 16 experimental fires conducted along a transect of sites in northern Australian savannas. After burning, the residues were partitioned into proximal and distal fluxes, each measured for their PyC and HyPyC contents and the carbon isotope composition of each component. The production of PyC across all experimental burns ranges from 11.6 to $23.1 \%$ of TCE. Total carbon exposed is positively correlated with fire residence time, and increasing fire residence time reduces the proportion of HyPyC produced due to the opportunity for more complete combustion. Thus, the short-lived fires occurring in grass-dominated ecosystems result in the production of proportionally more $\mathrm{HyPyC}$ compared to more woody-dominated savannas. The median (range) production of HyPyC as a proportion of both TCE and TCC across all experimental burns were 2.5 (4.9) and 2.9 (5.9) \%, respectively. These values are in good agreement with other estimates of black carbon (charcoal) production for savanna and grassland fires (Forbes et al., 2006). The relative amount of
HyPyC in the proximal flux is significantly larger in grassdominated savannas (up to $>99 \%$ ) compared to that observed in woodier savannas $(>86 \%)$. This is a significant observation as these two fluxes are likely to have different preservation potentials. The savanna isotope disequilibrium effect (SIDE, difference in carbon isotopic composition between grass biomass and pyrogenic carbon components) was highest at sites with the greatest proportion of grass biomass although this trend was only observed for the distal flux of fine-grained material $(<125 \mu \mathrm{m})$. Scaling the SIDE values observed here to the global savanna biome suggests that SIDE contributes a significant ${ }^{13} \mathrm{C}$ disequilibrium flux to the global mass balance of ${ }^{13} \mathrm{C}$ exchange between the atmosphere and other reservoirs (Ciais et al., 2005). The observation that SIDE increases with increasing grass biomass also suggests that frequently burned savannas are subject to depletion of ${ }^{13} \mathrm{C}$ in the pyrogenic products. As the PyC produced by savanna fires accumulates, either in situ or distally, SIDE produces soil or sedimentary organic carbon with $\delta^{13} \mathrm{C}$ values which are relatively ${ }^{13} \mathrm{C}$-depleted with respect to the original biomass. This effect may have significant implications for the interpretation of stable carbon isotopic composition of palaeo-records which are based wholly or in part on PyC.

Author contributions. G. Saiz, J. G. Wynn, I. Goodrick and M. I. Bird designed the experiment. G. Saiz and I. Goodrick carried out the fieldwork and conducted laboratory analyses. J. G. Wynn developed the model and performed simulations. G. Saiz, J. G. Wynn and M. I. Bird prepared the manuscript with contributions from all co-authors.

Acknowledgements. This work was supported by Australia Research Council Grants DP1096586 and FF0883221. We gratefully acknowledge Queensland Parks and Wildlife staff for access to sites at Undara and Davies Creek. We are also thankful to the Australian Wildlife Conservancy Society for allowing access and permits to undertake research at the Brooklyn Sanctuary site, and the generous farmer who granted us permission to work in his property near Corfield (MIT site).

The article processing charges for this open-access publication have been covered by a Research Centre of the Helmholtz Association.

Edited by: T. Keenan

\section{References}

Alden, C. B., Miller, J. B., and White, J. W. C.: Can bottom-up ocean $\mathrm{CO}_{2}$ fluxes be reconciled with atmospheric $13 \mathrm{C}$ observations?, Tellus B, 62, 369-388, 2010. 
Andreae, M. O. and Merlet, P.: Emission of trace gases and aerosols from biomass burning, Global Biogeochem. Cy., 15, 955-966, 2001.

Ascough, P. L., Bird, M. I., Brock, F., Higham, T. F. G., Meredith, W., Snape, C. E., and Vane, C. H.: Hydropyrolysis as a new tool for radiocarbon pre-treatment and the quantification of black carbon., Quaternary Geochronol., 4, 140-147, 2009.

Bird, M. I. and Ascough, P. L.: Isotopes in pyrogenic carbon: A review, Org. Geochem., 42, 1529-1539, 2012.

Bird, M. I. and Cali, J. A.: A million-year record of fire in subSaharan Africa, Nature, 394, 767-769, 1998.

Bird, M. I. and Gröcke, D. R.: Determination of the abundance and carbon isotope composition of elemental carbon in sediments, Geochim. Cosmochim. Ac., 61, 3413-3423, 1997.

Bird, M. I. and Pousai, P.: Variations of $\delta^{13} \mathrm{C}$ in the surface soil organic carbon pool, Global Biogeochem. Cy., 11, 313-322, 1997.

Bird, M. I., Moyo, C., Veenendaal, E. M., Lloyd, J., and Frost, P.: Stability of elemental carbon in a savanna soil, Global Biogeochem. Cy., 13, 923-932, 1999.

Bird, M. I., Wynn, J. G., Saiz G., Wurster C. M., and McBeath A.: The Pyrogenic Carbon Cycle, Ann. Rev. Earth Planet. Sci., 43, 9.1-9.26, 2015.

Blackford, J.: Charcoal fragments in surface samples following a fire and the implications for interpretation of subfossil charcoal data, Palaeogeogr. Palaeoclimatol. Palaeoecol., 164, 33-42, 2000.

Bond, T. C., Streets, D. G., Yarber, K. F., Nelson, S. M., Woo, J. H., and Klimont, Z.: A technology-based global inventory of black and organic carbon emissions from combustion, J. Geophys. Res., 109, D14203, doi:10.1029/2003JD003697, 2004.

Buchmann, N. and Ehleringer, J. R.: $\mathrm{CO}_{2}$ concentration profiles, and carbon and oxygen isotopes in $\mathrm{C}_{3}$ and $\mathrm{C}_{4}$ crop canopies, Agr. Forest Meteorol., 89, 45-58, 1998.

Cerling, T. E., Harris, J. M., MacFadden, B. J., Leakey, M. G., Quade, J., Eisenmann, V., and Ehleringer, J. R.: Global vegetation change through the Miocene/Pliocene boundary, Nature, 389, 153-158, 1997.

Cerling, T. E., Wynn, J. G., Andanje, S. A., Bird, M. I., Korir, D. K., Levin, N. E., Mace, W., Maccharia, A. N., Quade, J., and Remien, C. H.: Woody cover and hominin environments in the past 6 million years, Nature, 476, 51-56, 2011.

Ciais, P., Friedlingstein, P., Schimel, D. S., and Tans, P. P.: A global calculation of the $\delta^{13} \mathrm{C}$ of soil respired carbon: Implications for the biospheric uptake of anthropogenic $\mathrm{CO}_{2}$, Global Biogeochem. Cy., 13, 519-530, 1999.

Ciais, P., Cuntz, M., Scholze, M., Mouillot, F., Peylin, P., and Gitz, V.: Remarks on the use of ${ }^{13} \mathrm{C}$ and ${ }^{18} \mathrm{O}$ isotopes in atmospheric $\mathrm{CO}_{2}$ to quantify biospheric carbon fluxes, in: Stable Isotopes and Biosphere Atmosphere Interactions, Academic Press, San Diego, CA, 235-267, 2005.

Clark, J. S.: Particle motion and the theory of charcoal analysis: source area, transport, deposition and sampling, Quaternary Res., 30, 67-80, 1988.

Conedera, M., Tinner, W., Neff, C., Meurer, M., Dickens, A. F., and Krebs, P.: Reconstructing past fire regimes: methods, applications, and relevance to fire management and conservation, Quaternary Sci. Rev., 28, 555-576, 2009.

Cope, M. J. and Chaloner, W. G.: Fossil charcoal as evidence of past atmospheric composition, Nature, 283, 647-649, 1980.
Das, O., Wang, Y., and Hsieh, Y.-P.: Chemical and carbon isotope characteristics of ash and smoke derived from burning of $\mathrm{C}_{3}$ and $\mathrm{C}_{4}$ grasses, Org. Geochem., 41, 263-269, 2010.

Dittmar, T.: The molecular level determination of black carbon in marine dissolved organic matter, Org. Geochem., 39, 396-407, 2008.

Dittmar, T., de Rezende, C. E., Manecki, M., Niggemann, J., Ovalle, A. R. C., Stubbins, A., and Bernardes, M. C.: Continuous flux of dissolved black carbon from a vanished tropical forest biome, Nat. Geosci., 5, 618-622, 2012.

Domingues, T. F., Meir, P., Feldpausch, T. R., Saiz, G., Veenendaal, E. M., Schrodt, F., Bird, M. I., Djagbletey, G., Hien, F., Compaore, H., Diallo, A., Grace, J., and Lloyd, J.: Co-limitation of photosynthetic capacity by nitrogen and phosphorus along a precipitation gradient in West Africa, Plant, Cell and Environment, 33, 959-980, 2010.

Dümig, A., Rumpel C., Dignac M.-F., and Kögel-Knabner I.: The role of lignin for the $\delta^{13} \mathrm{C}$ signature in $\mathrm{C}_{4}$ grassland and $\mathrm{C}_{3}$ forest soils, Soil Biol. Biochem., 57, 1-13 2013.

Enting, I. G., Trudinger, C. M., and Francey, R. J.: A synthesis inversion of the concentration and $\mathrm{d} 13 \mathrm{C}$ of atmospheric $\mathrm{CO}_{2}$, Tellus B, 47, 35-52, 1995 .

Forbes, M. S., Raison, R. J., and Skjemstad, J. O.: Formation, transformation and transport of black carbon (charcoal) in terrestrial and aquatic ecosystems, Sci. Total Environ., 370, 190-206, 2006.

Furley, P. A., Rees, R. M., Ryan, C. M., and Saiz, G.: Savanna burning and the assessment of long-term fire experiments with particular reference to Zimbabwe, Prog. Phys. Geogr., 32, 611-634, 2008.

Haberle, S.: A $23000-y r$ pollen record from Lake Euramoo, Wet Tropics of NE Queensland, Australia, Quaternary Res., 64, 343356, 2005.

Hammes, K., Schmidt, M. W., Smernik, R. J., Currie, L. A., Ball, W. P., Nguyen, T. H., Louchouarn, P., Houel, S., Gustafsson, Ö., Elmquist, M., Cornelissen, G., Skjemstad, J. O., Masiello, C. A., Song, J., Peng, P., Mitra, S., Dunn, J. C., Hatcher, P. G., Hockaday, W. C., Smith, D. M., Hartkopf-Fröder, C., Böhmer, A., Lüer, B., Huebert, B. J., W., A., Brodowski, S., Huang, L., Zhang, W., Gschwend, P. M., Flores-Cervantes, D. X., Largeau, C., Rouzaud, J.-N., Rumpel, C., Guggenberger, G., Kaiser, K., Rodionov, A., Gonzalez-Vila, F. J., Gonzalez-Perex, J. A., de la Rosa, J. M., D.A.C., M., López-Capél, E., and Ding, L.: Comparison of quantification methods to measure fire-derived (black/elemental) carbon in soils and sediments using reference materials from soil, water, sediment and the atmosphere, Global Biogeochem. Cy., 21, doi:10.1029/2006GB002914, 2007.

Hartford, R. A. and Frandsen, W. H.: When it's hot, it's hot or maybe it's not!, (Surface flaming may not portend extensive soil heating), Int. J. Wildland Fire, 2, 139-144, 1992.

Keppler, F., Kalin, R. M., Harper, D. B., McRoberts, W. C., and Hamilton, J. T. G.: Carbon isotope anomaly in the major plant $\mathrm{C}_{1}$ pool and its global biogeochemical implications, Biogeosciences, 1, 123-131, doi:10.5194/bg-1-123-2004, 2004.

Krull, E. S., Skjemstad, J. O., Graetz, D., Grice, K., Dunning, W., Cook, G. D., and Parr, J. D.: ${ }^{13}$ C-depleted charcoal from $\mathrm{C}_{3}$ and $\mathrm{C}_{4}$ grasses and the role of occluded carbon in phytoliths., Org. Geochem., 34, 1337-1352, 2003.

Kuhlbusch, T. A. J., Andreae, M. O., Cachier, H., Goldammer, J. G., Lacaux, J. P., Shea, R., and Crutzen, P. J.: Black carbon formation 
by savanna fires: Measurements and implications for the global carbon cycle, J. Geophys. Res., 101, 23651-23623, 1996.

Lehmann, J., Skjemstad, J., Sohi, S., Carter, J., Barson, M., Falloon, P., Coleman, K., Woodbury, P., and Krull, E.: Australian climate-carbon cycle feedback reduced by soil black carbon, Nat. Geosci., 1, 832-883, 2008.

Lloyd, J. and Farquhar, G. D.: ${ }^{13} \mathrm{C}$ discrimination during $\mathrm{CO}_{2}$ assimilation by the terrestrial biosphere, Oecologia, 99, 201-215, 1994.

Loo, S. V. and Koppejan, J.: Handbook of biomass combustion and co-firing, Twente University Press, Enschede, the Netherlands, 2002.

Major, J., Lehmann, J., Rondon, M., and Goodale, C.: Fate of soilapplied black carbon: downward migration, leaching and soil respiration, Glob. Change Biol., 16, 1366-1379, 2010.

Masiello, C. A.: New directions in black carbon organic geochemistry, Mar. Chem., 92, 201-213, 2004.

Masiello, C. A. and Druffel, E. R. M.: Black carbon in deep-sea sediments, Science, 280, 1911-1913, 1998.

Meredith, W., Ascough, P. L., Bird, M. I., Large, D. J., Snape, C. E., Sun, Y., and Tilston, E. L.: Assessment of hydropyrolysis as a method for the quantification of black carbon using standard reference materials, Geochim. Cosmochim. Ac., 97, 131-147, 2012.

Miranda, A. C., Sinátora, H., Oliveira, I. F., and Ferreira, B.: Soil and air temperatures during prescribed cerrado fires in Central Brazil, J. Trop. Ecol., 9, 313-320, 1993.

O'Leary, M. H.: Carbon isotopes in photosynthesis, Bioscience, 38, 328-336, 1988.

O'Malley, V., Burke, R. A., and Schlotzhauer, W. S.: Using GCMS/Combustion/IRMS to determine the ${ }^{13} \mathrm{C} /{ }^{12} \mathrm{C}$ ratios of individual hydrocarbons produced from the combustion of biomass materials-applications to biomass burning, Org. Geochem., 27, 567-581, 1997.

Randerson, J. T., Van der Werf, G. R., Collatz, G. J., Giglio, L., Still, C. J., Kasibhatla, P., Miller, J. B., White, J. W. C., DeFries, R. S., and Kasischke, E. S.: Fire emissions from $\mathrm{C}_{3}$ and $\mathrm{C}_{4}$ vegetation and their influence on interannual variability of atmospheric $\mathrm{CO}_{2}$ and $\delta^{13} \mathrm{CO}_{2}$, Global Biogeochem. Cy., 19, GB2019, doi:10.1029/2004GB002366, 2005.

Rumpel, C., Alexis, M., Chabbi, A., Chaplot, V., Rasse, D. P., Valentin, C., and Mariotti, A.: Black carbon contribution to soil organic matter composition in tropical sloping land under slash and burn agriculture, Geoderma, 130, 35-46, 2006.

Saiz, G., Bird, M. I., Domingues, T., Schrodt, F., Schwarz, M., Feldpausch, T. R., Veenendaal, E. M., Djagbletey, G., Hien, F., Compaore, H., Diallo, A., and Lloyd, J.: Variation in soil carbon stocks and their determinants across a precipitation gradient in West Africa, Glob. Change Biol., 18, 1670-1683, 2012.

Saiz, G., Goodrick, I., Wurster, C., Zimmermann, M., Nelson, P., and Bird M. I.: Charcoal re-combustion efficiency in tropical savannas, Geoderma, 219/220, 40-45, 2014.

Santín, C., Doerr, S. H., Preston, C., and Bryant, R.: International Journal of Wildland Fire, Consumption of residual pyrogenic carbon by wildfire, 22, 1072-1077, 2013.

Santín, C., Doerr, S. H., Preston, C. M., and González-Rodríguez, G.: Pyrogenic organic matter production from wildfires: a missing sink in the global carbon cycle, Glob. Change Biol., doi:10.1111/gcb.12800, in press, 2015.
Seiler, W. and Crutzen, P. J.: Estimates of gross and net fluxes of carbon between the biosphere and the atmosphere from biomass burning, Clim. Change, 2, 207-247, 1980.

Still, C. J., Berry, J. A., Collatz, G. J., and DeFries, R. S.: Global distribution of $\mathrm{C}_{3}$ and $\mathrm{C}_{4}$ vegetation: carbon cycle implications, Global Biogeochem. Cy., 17, 1006, doi:10.1029/2001GB001807, 2003.

Thevenon, F., D., W., Bard, E., F.S., A., Beaufort, L., and Cachier, H.: Combining charcoal and elemental black carbon analysis in sedimentary archives: Implications for past fire regimes, the pyrogenic carbon cycle, and the human-climate interactions, Glob. Planet. Change, 72, 381-389, 2010.

Torello-Raventos, M., Feldpausch, T. R., Veenendaal, E. M., Schrodt, F., Saiz, G., Domingues, T., Djagbletey, G., Ford, A., Kemp, J., Marimon, B. S., Marimon, B. H. J., Lenza, E., Ratter, J. A., Maracahipes, L., Sasaki, D., Sonké, B., Zapfack, L., Taedoumg, H., Villarroel, D., Schwarz, M., Quesada, C. A., Ishida, F. Y., Nardoto, G. B., Affum-Baffoe, K., Arroyo, L., Bowman, D. M. J. S., Compaore, H., Davies, K., Diallo, A., Fyllas, N. M., Gilpin, M., Hien, F., Johnson, M., Killeen, T. J., Metcalfe, D., Miranda, H. S., Steininger, J., Thomson, J., Sykora, K., Mougin, E., Hiernaux, P., Bird, M. I., Grace, J., Lewis, S. L., Phillips, O. L., and Lloyd, J.: On the delineation of tropical vegetation types with an emphasis on forest/savanna transitions, Plant Ecol. Div., 6, 101-137, 2013

Trollope, W. S. W.: Fire in savanna, in Ecological Effects of Fire in South African Ecosystems, in, edited by: Booysen, P. D. V., and Tainton, N. M., Springer-Verlag, Berlin, Germany, 199-218, 1984.

van der Werf, G. R., Randerson, J. T., Giglio, L., Collatz, G. J., Mu, M., Kasibhatla, P. S., Morton, D. C., DeFries, R. S., Jin, Y., and van Leeuwen, T. T.: Global fire emissions and the contribution of deforestation, savanna, forest, agricultural, and peat fires (19972009), Atmos. Chem. Phys., 10, 11707-11735, doi:10.5194/acp10-11707-2010, 2010.

Wessel, P., Smith, W. H. F., Scharroo, R., Luis, J. F., and Wobbe, F.: Generic Mapping Tools: Improved version released, EOS Trans. AGU, 409-410, 2013.

Wright, H. A. and Bailey, A. W.: Fire ecology, John Wiley \& Sons, New York, 1982.

Wurster, C., Lloyd, J., Goodrick, I., Saiz, G., and Bird, M. I.: Quantifying the abundance and stable isotope composition of pyrogenic carbon using hydrogen pyrolysis, Rapid Commun. Mass Spectrom., 26, 2690-2696, 2012.

Wurster C. M., Saiz G., Schneider M. P. W., Schmidt M. W. I., and Bird M. I.: Quantifying pyrogenic carbon from thermosequences of wood and grass using hydrogen pyrolysis, Org. Geochem., 62, 28-32, 2013.

Wynn, J. G. and Bird, M. I.: C4-derived soil organic carbon decomposes faster than its C3 counterpart in mixed C3 / C4 soils, Glob. Change Biol., 13, 2206-2217, 2007.

Wynn, J. G. and Bird, M. I.: Environmental controls on the stable carbon isotopic composition of soil organic carbon: Implications for modelling the distribution of $\mathrm{C} 3$ and $\mathrm{C} 4$ plants, Australia, Tellus B, 60, 604-621, 2008.

Wynn, J. G., Bird, M. I., Vellen, L., Grand-Clement, E., Carter, J., and Berry, S. L.: Continental-scale measurement of the soil organic carbon pool with climatic, edaphic, 
and biotic controls, Global Biogeochem. Cy., 20, GB1007, doi:1010.1029/2005GB002576, 2006.

Zimmerman, A. R.: Abiotic and microbial oxidation of laboratoryproduced black carbon (biochar), Environ. Sci. Technol., 44, 1295-1301, 2010.
Zimmermann, M., Bird, M. I., Wurster, C., Saiz, G., Goodrick, I., Barta, J., Capek, P., Santruckova, H., and Smernik, R.: Rapid degradation of pyrogenic carbon, Glob. Change Biol., 18, 33063316, 2012. 